\title{
WALKING A TIGHTROPE WITHOUT A NET: VOLUNTARY AFFIRMATIVE ACTION PLANS AFTER WEBER
}

\author{
JEROME L. EPSTEIN ${ }^{\dagger}$
}

In 1979 the Supreme Court addressed for the first time the issue whether a private employer's voluntarily enacted affirmative action plan discriminated against a nonminority employee in violation of Title VII of the Civil Rights Act of 1964. ${ }^{1}$ The Court held in United Steelworkers $v$. Weber ${ }^{2}$ that Title VII's prohibition against race discrimination does not necessarily preclude affirmative action plans enacted voluntarily by private employers. ${ }^{3}$ Rather, Weber permits such raceconscious programs if they are initiated to correct "manifest racial imbalances in traditionally segregated job categories." The Court's reasoning implies that an employer that enacts a race-conscious plan without being able to demonstrate both a current underrepresentation of minorities and a history of segregation in the relevant job category will be found liable if a Title VII discrimination suit is brought by a nonminority plaintiff.

Affirmative action plans were challenged in two recent cases on the ground that the employers failed to establish that their plans were implemented in order to correct underrepresentation in traditionally segregated job categories. In Johnson $v$. Transportation Agency, ${ }^{5}$ the Court of Appeals for the Ninth Gircuit held that statistical evidence of

† B.S. 1983, Wharton School, University of Pennsylvania; J.D. Candidate 1986, University of Pennsylvania.

142 U.S.C. $\$ \S 2000 \mathrm{e}$ to $2000 \mathrm{e}-17$ (1982).

2443 U.S. 193 (1979).

See id. at 197.

4 Id. In addition to the Weber Court's primary concern with the circumstances under which an employer may implement an affirmative action program, the Court mentioned several considerations regarding the structure of a valid affirmative action program. The Weber plan was permissible because it was temporary and did not "unnecessarily trammel the interests of the white employees" or create an "absolute bar to the advancement of white employees." $7 d$. at 208. There has been much litigation concerning these structural requirements. See, e.g., Kromnick v. School Dist., 739 F.2d 894, 911-12 (3d Cir. 1984); Bushey v. New York State Civil Serv. Comm'n, 733 F.2d 220, 228 (2d Cir. 1984), cert. denied, 105 S. Ct. 803 (1985); Bratton v. City of Detroit, 704 F.2d 878, 897 (6th Cir. 1983), cert. denied, 464 U.S. 1040 (1984); Tangren v. Wackenhut Servs., 658 F.2d 705, 707 (9th Cir. 1981), cert. denied, 456 U.S. 916 (1982). This Comment, however, is concerned only with the question of when an employer may enact a plan without violating Title VII.

b 770 F.2d 752 (9th Cir. 1985). 
entrenched underrepresentation of women in the Santa Clara County Transportation Agency's skilled craft positions was sufficient to justify voluntary implementation of an affirmative action program. ${ }^{\bullet}$ Two days later, in Janowiak v. Corporate City of South Bend, ${ }^{7}$ the Court of Appeals for the Seventh Gircuit ruled that statistical evidence of underrepresentation of blacks in the South Bend Fire Department was insufficient to justify a voluntary affirmative action program; the court held that an employer must produce additional evidence of past discrimination in order to defend against a Title VII discrimination suit brought by a nonminority plaintiff. ${ }^{8}$

This disagreement between circuit courts is of great importance to all employers. ${ }^{9}$ Unless the Supreme Court resolves the controversy over what evidence is adequate to insulate affirmative action plans from Title VII attack, countless existing plans could be challenged and other employers could be deterred from implementing affirmative action programs. This Comment analyzes whether Weber requires an employer to show more than statistical evidence of underrepresentation of minorities $^{\mathbf{1 0}}$ in its work force to justify the implementation of an affirmative 754.

' See id. at 758 . Of the agency's 238 skilled craft workers, none was female. Id. at

750 F.2d 557 (7th Cir. 1984), petition for cert. filed, 53 U.S.L.W. 3896 (U.S. June 10,1985) (No. 84-1936). The decision in Johnson was originally handed down on December 4, 1984-two days prior to Janowiak-and then modified on September 5, 1985. See Johnson v. Transportation Agency, 748 F.2d 1308 (9th Gir. 1984), modified, 770 F.2d 752 (9th Cir. 1985). For a discussion of a significant amendment to the original Johnson decision, see infra text accompanying note 77.

S See Janowiak, 750 F.2d at 562.

${ }^{9}$ The Weber Court limited its holding to private employers. See 443 U.S. at 200. The two cases on which this Comment focuses involve public employers. See Johnson, 770 F.2d at 753-54; Janowiak, 750 F.2d at 558. In 1972 Congress amended Title VII to include public employers within the statutory definition of "employer." See Pub. L. No. 92-261, 86 Stat. 103, 103 (codified at 42 U.S.C. $\$ 2000$ e(b) (1982)). Since Weber, a number of decisions, in addition to Johnson and Janowiak, have applied Weber's guidelines to public agencies in Title VII suits. See, e.g., Bratton v. City of Detroit, 704 F.2d 878, 884 (6th Gir. 1983), cert. denied, 464 U.S. 1040 (1984); La Riviere v. EEOC, 682 F.2d 1275, 1279 (9th Cir. 1982). The Supreme Court recently declined an opportunity to address the question whether Weber can constitutionally be extended to public employers. See Bushey v. New York State Civil Serv. Comm'n, 105 S. Ct. 803 (1985), denying cert. to 733 F.2d 220, 227 n.8 (2d Cir. 1984) (concluding that Weber applies to public employers). The three Justices who dissented from the denial of certiorari noted that the denial may have been based on the petitioner's failure to press the fourteenth amendment equal protection argument on appeal. See Bushey, 105 S. Ct. at 806 (Rehnquist, J., dissenting). The question of the application of Weber to affirmative action plans enacted by public employers remains unanswered and is not addressed in this Comment. Even if the Court were to rule that Weber should not be extended to public employers, the issue addressed in this Comment would remain crucial to all private employers that wish to enact affirmative action plans.

10 In this Comment the terms "minority" and "nonminority" encompass sex-based classifications. 
action plan. Part I presents an analysis of Weber that considers both the standard the Supreme Court adopted and the options it rejected. Part II discusses the decisions in Janowiak and Johnson, highlighting the conflicts between the circuit courts' readings of Weber. In Part III the Comment explores these conflicting interpretations and suggests that both interpretations are supportable if considered solely within the parameters of the Supreme Court's opinion.

Finally, Part IV looks beyond the language of Weber to offer a resolution of this conflict. By defining the Weber standard in terms of the standards the Court rejected, and by presenting a comparison to the accepted use of statistics in Title VII actions brought by minority plaintiffs, the Comment concludes, as did the Ninth Circuit in Johnson, ${ }^{11}$ that an employer may comply with Weber by offering statistical data demonstrating manifest underrepresentation of minorities in its work force. The presentation of this evidence should create a strong presumption that the job category in question has traditionally been segregated. The plaintiff would then have the burden of demonstrating that because of methodological flaws the statistics do not support such an inference.

\section{Weber and the Paths Not Chosen}

\section{A. The Fifth Circuit's Decision}

To understand the true import of the Supreme Court's holding in Weber, it is first necessary to examine the majority and dissenting opinions in the Fifth Circuit Court of Appeals' consideration of the case. In Weber v. Kaiser Aluminum $\mathcal{O}^{\circ}$ Chemical Corp., ${ }^{12}$ the Fifth Circuit reviewed the affirmative action plan Kaiser had adopted as part of a master collective bargaining agreement with the United Steelworkers of America. ${ }^{13}$ The plan set hiring goals for blacks in the skilled craftworker positions in Kaiser's plants in order to equalize the percentages of blacks in the skilled craftworker positions and the local labor force. ${ }^{14}$ To accomplish these goals the plan provided that Kaiser establish on-the-job training programs to teach unskilled workers the skills necessary to become craftworkers, reserving fifty percent of the

11 Two other courts have approved the use of statistics to satisfy Weber. See Setser v. Novack Inv. Co., 657 F.2d 962, 968 \& n.6 (8th Cir. 1981); Tangren v. Wackenhut Servs., 480 F. Supp. 539, 547 (D. Nev. 1979), affd, 658 F.2d 705 (9th Cir. 1981), cert. denied, 456 U.S. 916 (1982).

12563 F.2d 216 (5th Cir. 1977), rev'd sub nom. United Steelworkers v. Weber, 443 U.S. 193 (1979).

13 See Weber v. Kaiser Aluminum, 563 F.2d at 218.

14 See id. 
openings in these programs for blacks. ${ }^{15}$

The court ruled that Kaiser's affirmative action plan violated the rights of nonminority workers under Title VII because Kaiser had produced no evidence that it had discriminated in the past, and therefore could not justify having implemented the plan. ${ }^{16}$ The court stated that Kaiser could not implement an affirmative action plan as a remedy for "societal discrimination." Instead, it could employ racial preferences only in order to remedy an imbalance that had resulted from its own past discriminatory acts. ${ }^{17}$

In dissent Judge Wisdom warned that the majority's holding spelled the end of voluntary compliance with Title VII. ${ }^{18}$ He reasoned that the majority rule forced the employer to walk a "high tightrope without a net."19 On one side of the rope, if the employer admitted to past discriminatory acts in order to justify an affirmative action plan, it would face the possibility of liability to minorities harmed by the admitted past discrimination. ${ }^{20}$ On the other side, the employer would risk liability to nonminorities if it adopted an affirmative action plan without meeting the majority's requirement that it admit to prior discrimination. ${ }^{21}$ Judge Wisdom suggested that employers would not be forced onto the tightrope if the majority's holding were replaced by an "arguable violation" test. Under this standard, any reasonable affirmative action plan enacted in response to an employer's arguable viola-

18 See id.

16 See id. at 224.

17 See id. at 224-25.

18 See id. at 230 (Wisdom, J., dissenting). Later in his opinion, Judge Wisdom tempered his prediction slightly, stating that the majority's standard would lead to "less voluntary compliance with Title VII." Id.

10 Id.

${ }^{20}$ See id. Observing that an employer has no incentive to prove past discrimination, one commentator has suggested that minorities and women who would benefit from affirmative action plans be joined as parties when affirmative action plans are attacked by nonminority employees. See Comment, The Distorted Adversarial Posture of Title VII Affirmative Action Challenges, 128 U. PA. L. REv. 1543, 1556-68 (1980). These employees would have every incentive to establish past discrimination in order to justify the voluntary implementation of their employer's affirmative action plan. One difficulty with this approach is that employers may still be reluctant to adopt affirmative action plans if past employer discrimination will be established in court, even if by another party.

${ }^{21}$ See Weber v. Kaiser Aluminum, 563 F.2d at 230 (Wisdom, J., dissenting). Justice Blackmun later pointed out in his concurring opinion in the Supreme Court's consideration of the case that employers faced yet another problem on the minority side of Wisdom's tightrope. If, recognizing the two dangers discussed in the text, the employer decided to forgo implementing an affirmative action plan, it would be precluded from attempting to mitigate any damages it had caused victims of its past discrimination. See United Steelworkers v. Weber, 443 U.S. at 211 (Blackmun, J., concurring). 
tions of Title VII would be lawful. ${ }^{22}$

\section{B. The Supreme Court's Decision}

Although Justice Blackmun endorsed Judge Wisdom's “arguable violation" theory in his Weber concurrence, ${ }^{23}$ a majority of the Supreme Court adopted neither the arguable violation standard nor the past discrimination requirement. ${ }^{24}$ The majority began its analysis by discussing the facts surrounding the operation of the plan at Kaiser's plant. After stating that Kaiser had long hired as craftworkers only persons who had had prior craft experience, ${ }^{28}$ the Court took judicial notice of the historical exclusion of workers from craft unions on racial grounds. ${ }^{26}$ Because of this historical segregation, the Gourt concluded that blacks lacked the credentials that Kaiser required for the craftworkers it sought to hire. As a result, there was a gross disparity between the percentage of blacks in Kaiser's skilled craft work force and the percentage of blacks in the labor force in the area of Kaiser's plant. $^{27}$

Praceeding to the merits of the claim, the Court emphasized that Kaiser was a private party and had voluntarily adopted the plan to eliminate "traditional patterns of racial segregation." ${ }^{\text {28 }}$ In this context, the prohibitions against racial discrimination in sections 703(a) and (d) of Title VII ${ }^{29}$ could not be read literally. Rather, these prohibitions had

${ }^{22}$ See Weber v. Kaiser Aluminum, 563 F.2d at 230 (Wisdom, J., dissenting). Judge Wisdom did not attempt to give content to the phrase "arguable violation." However, he reviewed the record and suggested that Kaiser had committed "three possible or probable violations" of Title VII. Id. at 231-32.

${ }^{23}$ See United Steelworkers v. Weber, 443 U.S. at 211 (Blackmun, J., concurring).

24 See id. at 209.

25 See id. at 198.

26 See id. at 198 n.1.

27 See id. at 198-99.

28 Id. at 201.

29 Section 703(a) provides:

(a) It shall be an unlawful employment practice for an employer-

(1) to fail or to refuse hire or to discharge any individual, or otherwise to discriminate against any individual with respect to his compensation, terms, conditions, or privileges of employment, because of such individual's race, color, religion, sex, or national origin; or

(2) to limit, segregate, or classify his employees or applicants for employment in any way which would deprive or tend to deprive any individual of employment opportunities or otherwise adversely affect his status as an employee, because of such individual's race, color, religion, sex, or national origin.

42 U.S.C. § 2000e-2(a) (1982).

Section 703(d) provides:

It shall be an unlawful employment practice for any employer, labor 
to be read "against the background of the legislative history of Title VII and the historical context from which the Act arose."30

In its analysis of the legislative history of the Act, the Court quoted from the remarks of several legislators, ${ }^{31}$ including Senator Humphrey who stated that Title VII was enacted to "open employment opportunities for Negroes in occupations which have been traditionally closed to them." "\$32 The Court also quoted a Report of the House Committee on the Judiciary indicating that Congress anticipated that Title VII would promote voluntary resolution of the problem of discrimination. ${ }^{33}$ The Court reasoned from the legislative history that Congress could not have intended to forbid private employers "from taking effective steps to accomplish the goal that Congress designed Title VII to achieve."34

As further support for its reading of the statute, the Court noted that section 703(j) states that nothing contained in Title VII " shall be interpreted to require any employer . . . to grant preferential treatment . . . to any group because of ' a de facto racial imbalance in the employer's workforce." 35 The use of the word "require" instead of the phrase "require or permit," reasoned the Court, indicated that Con-

organization, or joint labor-management committee controlling apprenticeship or other training or retraining, including on-the-job training programs, to discriminate against any individual because of his race, color, religion, sex, or national origin in admission to, or employment in, any program established to provide apprenticeship or other training.

42 U.S.C. $\S 2000 \mathrm{e}-2(d)$ (1982).

so United Steelworkers v. Weber, 443 U.S. at 201.

31 See id. at 202-07.

s2 Id. at 203 (quoting 110 CoNG. REC. 6548 (1964) (remarks of Sen. Humphrey)).

ss Id. at 203-04 (quoting H.R. REP. No. 914, 88th Cong., 1st Sess. 18 (1963), reprinted in 1964 U.S. CoDE CoNG. \& AD. News 2391, 2393). The House Report stated that "[t]here is reason to believe . . . that national leadership provided by the enactment of Federal legislation dealing with the most troublesome problems will create an atmosphere conducive to voluntary or local resolution of other forms of discrimination." H.R. REP. No. 914, 88th Cong., 1st Sess. 18 (1963), reprinted in 1964 U.S.

Code Cong. \& Ad. News 2391, 2393.

34 United Steelworkers v. Weber, 443 U.S. at 204

35 Id. at 205-06 (quoting Pub. L. No. 88-352, 78 Stat. 241, 257 (codified at 42 U.S.C. $\S 2000 \mathrm{e}-2(\mathrm{j})(1982))$. Section $703(\mathrm{j})$ provides:

Nothing contained in this subchapter shall be interpreted to require any employer, employment agency, labor organization, or joint labor-management committee subject to this subchapter to grant preferential treatment to any individual or to any group because of the race, color, religion, sex, or national origin of such individual or group on account of an imbalance which may exist with respect to the total number or percentage of persons of any race, color, religion, sex, or national origin employed by any employer. . . in comparison with the total number or percentage of persons of such race, color, religion, sex, or national origin in any commu- 
gress did not intend to forbid voluntary race-conscious affirmative action plans. ${ }^{36}$

The Gourt concluded that Title VII left to private employers an area of discretion in which they were free "voluntarily to adopt affirmative action plans to eliminate conspicuous racial imbalance in traditionally segregated job categories." ${ }^{\text {"3z }}$ In so holding, the Court rejected both the Fifth Circuit majority's "past discrimination" approach and Judge Wisdom's "arguable violation" approach.

\section{The Decisions In Janowiak AND Johnson}

\section{A. Janowiak v. Corporate City of South Bend}

In Janowiak v. Corporate City of South Bend, ${ }^{38}$ a white male who had been denied employment with the city fire department because of the operation of the city's affirmative action program challenged the legality of that program under Title VII. In the court's words, the challenge presented the issue whether "the Gity of South Bend could adopt an affirmative action program for its Police and Fire Departments solely upon the basis of a finding that a disparity existed between the percentage of minorities in the population of South Bend and the percentage of minorities in the Departments."39

The Seventh Circuit pointed to the Weber Court's judicial notice of the craft unions' history of excluding blacks from membership, and concluded that in Weber the Court "relied upon more than the glaring statistical. disparity between the percentage of black craftworkers employed and the percentage of blacks in the workforce." 40 Based on this reasoning the Janowiak court read Weber as requiring that an affirmative action program be based upon a finding of "past discrimination."41

nity, State, section, or other area, or in the available work force in any community, State, section, or other area.

42 U.S.C. $\$ 2000 \mathrm{e}-2(j)(1982)$.

si See United Steelworkers v. Weber, 443 U.S. at 206. The Court also argued that its reading of the legislative history was fully consistent with the legislators' concern that the federal government not interfere with traditional management prerogatives, specifically the freedom to address racial imbalance in the work force. See id. at 20607.

37 Id. at 209.

38750 F.2d 557 (7th Gir. 1984).

s9 Id. at 558.

${ }^{10}$ Id. at 562 (citing United Steelworkers v. Weber, 443 U.S. at 198-99).

41 See id. The Seventh Circuit did not specifically state whether "past discrimination" meant past discrimination by the employer or past societal discrimination. There can be little doubt, however, that the court was referring to societal discrimination; to hold otherwise would have directly contradicted the Supreme Court's holding in Weber. Since the Janowiak opinion cited and quoted Weber at length, it is likely that the 
The court further stated that Weber "hinged on" the judicial notice of the exclusion of blacks from craft unions, ${ }^{42}$ and cited its own statement in a prior case that "statistical data constitutes 'the first step in assessing whether [an] employer decides properly to institute an affirmative action plan." "48 Under Weber and its own previous decision, the court concluded, an employer could not adopt an affirmative action program "in response to a finding of past discrimination based solely upon a statistical disparity."44

\section{B. Johnson v. Transportation Agency}

In Johnson v. Transportation Agency, ${ }^{45}$ a male employee of the Santa Glara County Transportation Agency brought an employment discrimination action alleging that he was illegally denied promotion on the basis of sex because of the operation of the agency's affirmative action program. Rejecting the district court's concern that the plan was not addressed to breaking down entrenched patterns of discrimination, the court determined that in order to justify an affirmative action program, "an employer need not show its own history of purposeful discrimination. It is sufficient for the employer to show a conspicuous imbalance in its work force."48 Discussing why statistics alone are enough to justify an affirmative action program, the court stated:

Statistics are extremely useful in showing a conspicuous work force imbalance. We note particularly the difficulty that may confront an employer whose plan is intended to remedy discrimination resulting from societal norms. Some forms of discrimination are so subtle or so accepted that they defy proof other than by statistics. ${ }^{47}$

Thus, the Johnson court, unlike the court in Janowiak, held that statis-

phrase "past discrimination" was used to refer to past societal discrimination.

42 See id.

43 Id. at 563 (quoting Lehman v. Yellow Freight Sys., 651 F.2d 520, 527 (7th Cir. 1981)).

4 Id.

18770 F.2d 552 (9th Cir. 1985).

68 Id. at 758 (citation and footnote omitted).

47 Id. At this point, the Johnson court cryptically referred to the Supreme Court's taking judicial notice of the historical exclusion of blacks from craft unions. See id. (citing United Steelworkers v. Weber, 443 U.S. at 198 n.1). Perhaps the court cited Weber's footnote one to show that while in some cases of discrimination statistics will be the only available means of proof, in rare cases it may be possible to establish traditionally segregated job categories by other means. The Johnson court explicitly held, however, that statistics are sufficient to establish a traditionally segregated job category. See id. 
tical evidence of minority underrepresentation in the relevant job category was sufficient to justify an employer's affirmative action plan.

\section{INTERPRETING THE Weber STANDARD}

\section{A. Arguable Violations Versus Traditionally Segregated Job Categories}

The Seventh Circuit's holding in Janowiak, that proof of underrepresentation of minorities in a job category is insufficient to show that the job category had traditionally been segregated, ignores the Supreme Court's rejection of the "prior discrimination" and "arguable violation" approaches suggested by the majority and dissenting opinions in the Fifth Circuit's consideration of Weber.

Judge Wisdom had proposed the "arguable violation" theory because an actual prior discrimination requirement would be too harsh on employers. ${ }^{48}$ The Supreme Court, however, imposed an even lighter burden on employers by requiring that they show only that the job category in question was traditionally segregated.

Justice Blackmun's concurring opinion in Weber, in which he specifically joined the opinion of the Court ${ }^{49}$ but explained that he nonetheless preferred the arguable violation standard, ${ }^{\mathbf{5 0}}$ discussed the differences between the "arguable violation" and "traditionally segregated job category" standards: "Traditionally segregated job categories,' where they exist, sweep far more broadly than the class of 'arguable violations." "' Justice Blackmun preferred the "narrow" arguable violation approach and criticized the Court's "expansive approach."

According to Justice Blackmun, the Court's approach "depart[ed] from the 'arguable violations' approach [in] that it measure[d] an individual employer's capacity for affirmative action solely in terms of a statistical disparity." "'53 Justice Blackmun concluded that he could accept the majority's more expansive reading of the statute precisely because he recognized that the arguable violation standard would probably be met in practice by statistical evidence:

To make the "arguable violation" standard work, it would have to be set low enough to permit the employer to prove it without obligating himself to pay a damage award. The in-

\footnotetext{
18 See supra notes $18-22$ and accompanying text.

49 See United Steelworkers v. Weber, 443 U.S. at 209 (Blackmun, J., concurring).

so See id. at 211.

s1 Id. at 212.

s2 See id. at 212-13.

s3 Id. at 213 (emphasis added).
} 
evitable tendency would be to avoid hairsplitting litigation by simply concluding that a mere disparity between the racial composition of the employer's work force and the composition of the qualified local labor force would be an "arguable violation," even though actual liability could not be established on that basis alone. ${ }^{54}$

Although the majority of the Court might not have agreed with Justice Blackmun's analysis of the differences between the "traditionally segregated job category" and "arguable violation" standards, there is support in the majority opinion for the proposition that an employer can establish a traditionally segregated job category without having to prove an arguable violation of Title VII. The Court specifically stated that its approach should not be read "to suggest that the freedom of an employer to undertake race-conscious affirmative action efforts depends on whether or not his effort is motivated by fear of liability under Title VII."'ss

In light of the clear progression from the Fifth Circuit's requirement of an actual violation to Judge Wisdom's lesser requirement of an arguable violation to the Supreme Court's even more lenient requirement that the employer show a traditionally segregated job category, Weber appears to require no more than statistical evidence of entrenched underrepresentation in the relevant job category. However, Weber's footnote one, in which the Court took judicial notice of the historical exclusion of blacks from craft unions, ${ }^{56}$ suggests that Weber may require more than mere statistical evidence of underrepresentation of minorities.

\section{B. The Conflict over Weber's Footnote One}

The judicial notice taken in Weber was based on six cases, a number of books, and several reports by the United States Commission on Civil Rights. From these sources, the Court concluded that "blacks had long been excluded from craft unions." not implicate themselves in justifying the creation of affirmative action

of Id. at 214 .

SB Id. at $208 \mathrm{n} .8$. Judge Wallace, in his separate opinion in Johnson, misread the Court's rejection of the arguable violation standard, concluding erroneously that the Weber test is more stringent on an employer than the arguable violation requirement would have been. See Johnson, 770 F.2d at 764 (Wallace, J., concurring in part and dissenting in part). The Johnson majority observed this error made by the dissent. See id. at 758 n.5.

${ }^{\circ 6}$ See United Steelworkers v. Weber, 443 U.S. at 198 n.1.

67 Id. at 198 \& n.1. 
plans, Weber arguably requires documentary evidence of societal or industrial discrimination in addition to evidence of historical underrepresentation. As noted above, the Janowiak court seized on Weber's judicial notice as evidence that "the Court relied upon more than the glaring statistical disparity between the percentage of black craftworkers employed and the percentage of blacks in the workforce."

By giving such import to footnote one, it is possible to read Weber as requiring employers to gather case law and other literature demonstrating historical segregation. If this standard were applied in future cases concerning voluntarily enacted affirmative action programs, some employers, such as those that employ craftworkers, police officers, college professors, and arguably all public employees, could rely on judicial notice taken in existing case law. ${ }^{88}$ For other employers, however, it would be considerably more difficult to locate such information. ${ }^{60}$

Should the agency in Johnson have been required to undertake a search of case law for judicial findings of historical discrimination against female road maintenance workers? Would it have sufficed to produce cases finding discrimination against women in blue collar occupations or in the government in general? While it appears that the Janowiak court would have wanted some form of additional proof, for the court in Johnson it was sufficient that the agency had shown that not one of its 238 skilled craftworkers was a woman. As long as footnote one is read in a vacuum, the conflict between the two circuit courts cannot be resolved.

${ }^{68}$ Janowiak, 750 F.2d at 562; see supra text accompanying notes $42-44$.

${ }^{69}$ See, e.g., United States v. Gity of Alexandria, 614 F.2d 1358, 1363 n.12 (5th Cir. 1980) (citing judicial, administrative, and congressional findings of discrimination by municipal police and fire departments); United States v. City of Miami, 614 F.2d 1322, 1338 n.29 (5th Cir. 1980) (citing congressional findings of discrimination by public sector employees), modified, 664 F.2d 435 (1981); Detroit Police Officers' Ass'n v. Young, 608 F.2d 671, 690-91 (6th Cir. 1979) (citing judicial and administrative findings of unlawful discrimination by law enforcement agencies), cert. denied, 452 U.S. 938 (1981); Cohen v. Community College, 484 F. Supp. 411, 434 (E.D. Pa. 1980) (citing law review articles discussing historical discrimination in higher education).

Bo One commentator noted that "it is a plausible contention that every job classification in America today has been traditionally closed to both women and minorities." Comment, Voluntary Affirmative Action After United Steelworkers of America v. Weber: Constructing a Peaceful Coexistence Between Title VII and Executive Order 11,246, 27 UCLA L. REv. 1159, 1182 (1980). Had the Weber Court accepted this proposition, it would have required that an employer show only a present racial imbalance in the relevant job category to justify the employer's affirmative action plan. 


\section{Resolving the Gonflict}

The preceding sections of this Comment have demonstrated that the Weber decision clearly precludes forcing an employer to admit to having discriminated or arguably discriminated in the past in order to justify implementing an affirmative action plan. Beyond this, however, Weber is open to contradictory interpretations. The Court's rejection of both the "actual discrimination" and "arguable violation" standards suggested by the Fifth Circuit's majority and dissent indicates that statistical evidence of current underrepresentation of minorities in the relevant job category is sufficient to meet the requirement of traditional segregation in that job category. Some courts, however, have read footnote one of the Weber majority opinion as suggesting that an employer must also point to judicial or other findings that industrial or societal discrimination has operated to keep the relevant job category closed to minorities.

The solution to this conflict is impossible to discern within the parameters of Weber alone. The conflict arises because it is unclear what weight should be given to Weber's footnote one. For the Janowiak court, the decision in Weber "hinged on" footnote one. ${ }^{61}$ By examining the Supreme Court's rulings on the use of statistical evidence of underrepresentation in Title VII claims by minority plaintiffs, and by reexamining the concerns that led the Court to eschew requiring employers to prove arguable violations, the solution to this crucial problem can be determined.

\section{A. An Obvious Answer? A Comparison to the Use of Statistics in Disparate Treatment Actions}

The Supreme Court first set forth the order and allocation of proof in Title VII "disparate treatment"62 actions in McDonnell Doug-

B1 See Janowiak, 750 F.2d at 562.

62 Disparate impact and disparate treatment are the two basic types of liability under section 703(a) of Title VII, 42 U.S.C. $\$ 2000 \mathrm{e}-2$ (a) (1982). The Court succinctly described the difference between disparate treatment and disparate impact in International Bhd. of Teamsters v. United States, 431 U.S. 324 (1977):

"Disparate treatment" . . . is the most easily understood type of discrimination. The employer simply treats some people less favorably than others because of their race, color, religion, sex, or national origin. Proof of discriminatory motive is critical, although it can in some situations be inferred from the mere fact of differences in treatment. . . .

Claims of disparate treatment may be distinguished from claims that stress "disparate impact." The latter involve employment practices that are facially neutral in their treatment of different groups but that in fact fall more harshly on one group than another and cannot be justified by 
las Corp. v. Green ${ }^{63}$ and later refined these requirements in Texas Department of Community Affairs $v$. Burdine. ${ }^{64}$ In such actions the plaintiff must first establish a "prima facie case of racial discrimination."65 If the plaintiff succeeds in making out a prima facie case, the burden of production shifts to the employer to articulate some legitimate, nondiscriminatory reason for having rejected the plaintiff. ${ }^{66} \mathrm{Fi}$ nally, should the defendant carry this burden the plaintiff then has an opportunity to prove by a preponderance of the evidence that the legitimate reasons offered by the defendant were not its true reasons, but were a pretext for discrimination. ${ }^{67}$

In International Brotherhood of Teamsters $v$. United States, ${ }^{68}$ the Court stated that the government may use statistical evidence of racial or ethnic imbalance to make out a prima facie case of a pattern or practice of discrimination:

Statistics showing racial or ethnic imbalance are probative in a case such as this one only because such imbalance is often a telltale sign of purposeful discrimination; absent explanation, it is ordinarily to be expected that nondiscriminatory hiring practices will in time result in a work force more or less representative of the racial and ethnic composition of the population in the community from which employees are hired. ${ }^{\text {eg }}$

The Court clarified any ambiguity that may have remained after

business necessity. . . . Proof of discriminatory motive, we have held, is not required under a disparate-impact theory.

Id. at 335 n.15. Under the category of disparate treatment, an additional distinction can be made between individual disparate treatment, in which an individual claims that she has been treated less favorably because of her group status, and systemic disparate treatment, in which a class of individuals or the government alleges a "pattern or practice" of discrimination. See M. Zimmer, G. Sullivan \& R. RichardS, CaSES AND Materials on Employment Discrimination 3-7 (1982).

63411 U.S. 792 (1973).

ot 450 U.S. 248 (1981).

6s McDonnell Douglas, 411 U.S. at 802 . The Court suggested that the plaintiff could accomplish this by showing the following: that she belonged to a racial minority; that she applied and was qualified for a job for which the employer was seeking applicants; that she was rejected despite her qualifications; and that after her rejection the position remained open and the employer continued to seek applicants from persons of the plaintiff's qualifications. See id. The Court emphasized, however, that this was simply an example of how a plaintiff could make out a prima facie case of discrimination and was not the only way. See id. n.13.

${ }_{68}$ See Burdine, 450 U.S. at 254-55.

67 See id. at 256.

B8 431 U.S. 324 (1977).

68 Id. at 340 n.20. 
Teamsters in Hazelwood School District $v$. United States, ${ }^{\mathbf{7 0}}$ stating that "[w]here gross statistical disparities can be shown, they alone may ... constitute prima facie proof of a pattern or practice of discrimination."

Whether an analogy can be drawn from the use of statistics in a disparate treatment action brought by the government or minorities to the use of statistics by an employer trying to satisfy Weber's requirements is a difficult question. Several courts, however, have explicitly drawn this analogy. In Tangren $v$. Wackenhut Services, ${ }^{72}$ the court stated that "[c]ourts have consistently held that statistical evidence is sufficient to establish a prima facie case of unlawful discrimination."73 The Tangren court concluded that "[i]f such a showing is sufficient to permit the imposition of legal sanctions, a fortiori, the same showing should permit an employer and union to adopt a voluntary affirmative action program."74

Similar logic was used by the Court of Appeals for the Eighth Circuit in Setser $v$. Novack Investment Co. ${ }^{78}$ Relying on Weber's rejection of the arguable violation standard, the court stated that a statistical showing of a "conspicuous racial imbalance" satisfies Weber "even if the statistics employed would not be sufficient to show a prima facie violation of title VII." ${ }^{\prime \prime 6}$ In addition, the Ninth Circuit, in a significant amendment to its original decision in Johnson, observed that while Weber does not require that an employer establish an arguable violation, the statistical evidence in Johnson could have been used to establish a prima facie case of discrimination. ${ }^{77}$ Unfortunately, however, none of these courts explained the analogy between the use of statistics in the Weber context and the use of statistics to establish a prima facie case of discrimination.

By considering more closely the relationship between the the use of statistics in disparate treatment actions and the use of statistics in

20433 U.S. 299 (1977).

71 Id. at 307-08 (citing Teamsters, 431 U.S. at 339).

${ }^{72} 480$ F. Supp. 539 (D. Nev. 1979), affd, 658 F.2d 705 (9th Cir. 1981), cert. denied, 456 U.S. 916 (1982).

${ }^{73}$ Id. at 547 .

74 Id.

75 657 F.2d 962 (8th Cir. 1981).

${ }^{78} I d$. at 968 (footnote omitted).

77770 F.2d at 758 n.5 (citing United Steelworkers v. Weber, 443 U.S. at 208 n.8). In addition to the three courts, one commentator has suggested, without elaborating, that "[s]ince . . . an employee can establish a Title VII violation merely by statistically showing underrepresentation of minorities in its work force, an employer should be permitted to take affirmative action to prevent such a confrontation." Comment, supra note 60, at 1185. 
actions like Weber, ${ }^{78}$ it is possible to develop a line of reasoning that is implicit in Tangren, Setser, and Johnson. The first premise is that since the Weber Court refused to require the employer to prove an arguable violation, any proof of an arguable violation would meet the more lenient Weber test. Second, a prima facie case of discrimination and an arguable violation as conceived by Judge Wisdom and Justice Blackmun are functionally equivalent. ${ }^{79}$ Third, in disparate treatment Title VII suits, statistics can be used to establish a prima facie case of discrimination. Therefore, statistical disparity evidence satisfies the Weber standard.

The problem with this logic is that the conclusion does not necessarily follow from the third premise. The conclusion that a conspicuous disparity has been demonstrated by statistics establishing a prima facie case of discrimination rests on the assumption that relevant samples were selected for comparison. If an employer rebuts a prima facie case of discrimination by successfully attacking the statistical methodology, the employer may also succeed in demonstrating the absence of any disparity. For example, assume a group of minority schoolteachers alleging discrimination offered evidence that there was a gross disparity between the percentage of minority teachers employed in a school district and the percentage of minority students in that district. The school district might rebut this evidence of discrimination by arguing that the correct sample for comparison should be the percentage of qualified minority applicants in the local work force, not the percentage of students. ${ }^{80}$ If the school district's argument were accepted, the employer

${ }^{78}$ This Comment draws an analogy to the use of statistics in disparate treatment actions because these actions, unlike disparate impact actions, involve "an overall attack on the results of hiring without any focus on particular employment rules or procedures." C. Sullivan, M. Zimmer \& R. Richards, Federal Statutory Law of EMPloyment Discrimination 32 (1980). An employer attempting to satisfy the Weber test is not concerned with any particular employment practice, but rather with demonstrating a pattern or history of segregation. For this reason the analogy to disparate treatment actions seems more appropriate. It should be noted, however, that statistics are also used to establish a prima facie case in disparate impact actions, and there is much overlap between the use of statistics in disparate treatment and disparate impact actions. See id. at 30-33.

70 By definition a prima facie case of discrimination establishes an arguable violation. See Burdine, 450 U.S. at 254 (prima facie case creates a presumption of unlawful discrimination); Furnco Constr. Co. v. Waters, 438 U.S. 567, 577 (1978) (prima facie case raises an inference of discrimination). The Johnson court used the terms "prima facie violation" and "arguable violation" interchangeably. See Johnson, 770 F.2d at 758 n.5.

${ }^{80}$ A comparison of the percentage of schoolteachers to the percentage of minority students in a school district has been rejected by the Supreme Court where the comparison was used by a school district to show an absence of discrimination. See Hazelwood, 433 U.S. at 303, 308. One circuit court permitted such a comparison where it was used as evidence of underrepresentation of minority schoolteachers in an equal protection 
would succeed not only in proving an absence of discrimination but also in proving an absence of underrepresentation. Thus, the employer in the traditional Title VII disparate action suit does not have to explain an asserted statistical imbalance if it shows that there are no valid statistics to explain. The logic suggested above by the Tangren, Setser, and Johnson courts succeeds only if the statistical sampling establishes underrepresentation of minorities. The problems of statistical sampling, which have been discussed extensively in disparate treatment literature ${ }^{81}$ inhere in the use of statistics and will therefore be present in the "reverse discrimination" setting as well.

Given that such problems can exist whenever statistical evidence is used, disputes will inevitably arise as to the validity of the statistics offered by employers seeking to justify the enactment of affirmative action plans. It is necessary, therefore, to determine the proper allocation of proof regarding the question of the validity of statistical evidence of underrepresentation.

\section{B. The Litigants' Roles in Weber Litigation}

The reasoning suggested above is helpful in understanding how the parties to a reverse discrimination action would seek to use and to attack the use of statistical evidence. After a nonminority plaintiff brought suit alleging that an affirmative action plan was discriminatory, an employer could defend its use of the plan by arguing that statistical evidence of a "manifest" or "conspicuous" underrepresentation of minorities establishes an arguable Title VII violation, ${ }^{\mathbf{8 2}}$ and therefore satisfies the more lenient Weber test. The only way to attack this

challenge to a school district's affirmative action plan. See Wygant v. Jackson Bd. of Educ., 746 F.2d 1152, 1156 (6th Cir. 1984), cert. granted, 105 S. Ct. 2015 (1985). It remains to be seen whether the Supreme Court will agree.

81 See, e.g., D. Baldus \& J. Cole, Statistical Proof of Discrimination 115-21 (1980) (discussing evaluation and specification of proxy populations in lieu of applicant data); C. Sullivan, M. ZIMMER \& R. Richards, supra note 78, at 25-29 (explaining ways the available labor pool figure can be manipulated); Boardman \& Vining, The Role of Probative Statistics in Employment Discrimination Cases, LAw \& CONTEMP. ProBs., Autumn 1983, at 189, 193-201 (discussing five ways to sample the number of minorities employed and four ways to sample the reference group in the population at large).

${ }^{82}$ This Comment does not attempt to define the magnitude of disparity necessary to establish a "manifest" or "conspicuous" imbalance. In Weber $1.83 \%$ of the skilled craftworkers were black, compared to a local work force that was $39 \%$ black. See Weber, 443 U.S. at 198-99. The disparity in Janowiak was less severe-5.3\% minorities in the fire department compared to $14.1 \%$ in the population. See Janowiak, 750 F.2d at 558. In Johnson, all of the agency's 238 skilled craft positions were held by men. See Johnson, 770 F.2d at 754. For a thorough discussion of the legal and statistical aspects of what constitutes a "significant" disparity in Title VII actions, see Boardman \& Vining, supra note 81 , at 201-17. 
argument is to assert that the employer's statistics are insufficient to establish manifest underrepresentation. Some evidence is needed to establish the validity of the employer's statistical sample. To require the employer to establish the sample's validity, however, would be to force the employer back on the tightrope: the employer could implicate itself by providing statistical data that too strongly suggest that it has violated Title VII. If an employer is forced to prove precisely the reliability of its statistical data it will be exposing itself to the possibility of disparate treatment suits by minority employees. By having to defend its selection of a certain geographical pool or time frame, the employer could be forced to demonstrate that it has discriminated. At the same time, however, such an employer should not be permitted to satisfy Weber with statistics that are methodologically unsound.

The solution to this tension is to require that a nonminority plaintiff in a reverse discrimination suit play the role usually played by the employer-defendant in a disparate treatment suit. Thus, if the employer in a reverse discrimination suit presents evidence of manifest past and present underrepresentation of minorities in its work force, the result should be a strong presumption that the job category is "traditionally segregated." The nonminority plaintiff can then rely on disparate treatment case law to rebut the presumption, arguing, for example, that the employer compared its work force composition to an irrelevant sample population. ${ }^{83}$

The role reversal analogy is not perfect. In a disparate treatment action a minority plaintiff may use statistics to establish that the employer intended to discriminate. ${ }^{84}$ The employer may respond by arguing that the statistical sampling, while demonstrating minority underrepresentation, does not suggest intentional discrimination in violation

83 For a discussion of what constitutes a "relevant" sample population, see Boardman \& Vining, supra note 81 , at 193-201. The authors note that there is wide debate over the choice of a sample of employees and a sample of the reference population. See id. at 193. They categorize five possible ways to sample the "protected" minority group: employer's total work force; work force at a particular level; recent hires to whole firm; recent hires, assignments, or promotions to particular level, type, or division; and candidates for hire or promotion. See id. at 196. Boardman and Vining then describe four possible "reference" groups: general population, qualified work pool, applicant pool, and another level within the firm. Id. That there are 20 possible permutations of statistical comparisons, some of which are used more frequently and successfully than others, demonstrates that the use of statistics in employment discrimination is unsettled. It is not the intent of this Comment to analyze the methods by which a statistical sample can be attacked. The purpose of the analogy between Weber and disparate treatment case law is to illustrate that a nonminority plaintiff can use existing case law to challenge the validity of an employer's statistical sample.

st See supra text accompanying notes 68-71. 
of Title VII. ${ }^{85}$ For example, if there were very few minority applicants for a certain job, and the low application rate was not attributable to any discriminatory acts by the employer, a court could find that there was an underrepresentation of minorities but no intentional discrimination by the employer.

However, if a nonminority plaintiff in a reverse discrimination suit were to play the role of the above employer by citing applicant pool data in order to show that Weber was not satisfied, she would not prevail. The role-playing analogy breaks down in such a case because Weber does not require past discrimination by the employer in order to justify an affirmative action plan. It is irrelevant to the Weber analysis that a firm has no minority workers because none applied. A nonminority plaintiff responding to an employer's Weber defense must prove that the statistics supplied by the employer are so flawed that they do not show manifest underrepresentation at all. If a nonminority plaintiff cannot rebut the employer's statistics by showing a flawed design, the evidence of past and present underrepresentation of minorities must be presumed to establish an arguable Title VII violation, and therefore a traditionally segregated job category.

\section{CoNCLUSION}

To immunize itself against a discrimination suit by a nonminority plaintiff, an employer that has enacted an affirmative action plan must satisfy Weber's requirement that the plan be designed to correct "manifest racial imbalances in traditionally segregated job categories." though the employer bears the burden of establishing the validity of its race-conscious plan, it is clear from the Weber Court's rejection of the Fifth Circuit majority and dissenting opinions that the employer cannot be required to establish its own actual past discrimination or arguable violations of Title VII.

Circuit courts have disagreed, however, as to whether providing evidence of underrepresentation of minorities in the relevant job category satisfies the employer's burden. Justice Blackmun read the majority opinion as sanctioning the use of evidence of minority underrepresentation to justify an affirmative action plan, ${ }^{87}$ but the Janowiak court, relying on the Weber majority's judicial notice of historical dis-

8s For examples of reasons why statistical evidence may not establish intentional discrimination, see Note, Employment Discrimination-Weber v. Kaiser Aluminum \& Chemical Corp.: Does Title VII Limit Executive Order 11246?, 57 N.C.L. REv. 695, 716 n.105 (1979).

${ }^{86}$ United Steelworkers v. Weber, 443 U.S. at 197.

${ }^{87}$ See id. at 212 (Blackmun, J., concurring). 
crimination by craft unions, required further evidence of past discrimination in the relevant job category. ${ }^{88}$ The Janowiak court failed to recognize the probative value of statistics in disparate treatment actions, in which a prima facie case of discrimination can be established by the use of statistical evidence of underrepresentation. Because a prima facie case of discrimination in a disparate treatment action is equivalent to an arguable violation, and because the Weber standard is less strict than an arguable violation standard, several courts have concluded that statistical data that create a prima facie case of disparate treatment necessarily satisfy Weber. ${ }^{89}$ These courts have improperly assumed, however, that an employer's statistical methodology is necessarily sound.

Since an employer need not establish an arguable violation of Title VII in order to enact a race-conscious plan, it cannot be forced to provide statistical support of its data that is so detailed as to implicate it in discriminatory conduct. Rather, evidence of manifest past and present underrepresentation should suffice to create a strong presumption that the job category has traditionally been segregated, placing the burden on the nonminority plaintiff to show that, because of errors in the statistical methodology, conspicuous underrepresentation cannot validly be inferred. This approach to nonminority challenges to voluntarily enacted affirmative action plans avoids forcing employers onto the Title VII tightrope.

88 See Janowiak, 750 F.2d at 562.

${ }^{89}$ See Johnson, 770 F.2d at 758; Setser v. Novack Inv. Co., 657 F.2d 962, 968 \& n.6 (8th Gir. 1981); Tangren v. Wackenhut Servs., 480 F. Supp. 539, 547 (D. Nev. 1979), affd, 658 F.2d 705 (9th Gir. 1981), cert. denied, 456 U.S. 916 (1982). 
